\title{
НАШ ГАГАРИН
}

\section{И.Б. Соловьева}

Канд. психол. наук, ст.н.с., космонавт-испытатель И.Б. Соловьева (ФГБУ «НИИ ЦПК имени ЮА Гагарина»)

В статье автор обращается ко времени начала космической эры человечества, к личности первого космонавта планеты - Юрия Алексеевича Гагарина. Ключевые слова: первый отряд, космический полет, первый космонавт.

\section{Our Gagarin. I.B. Solovyova}

The author addresses to the time of the beginning of the space age of mankind and to the personality of Yuri Alekseyevich Gagarin, the first cosmonaut of the planet.

Keywords: first cosmonaut corps, spaceflight, first cosmonaut.

7 марта 2020 года отмечается важная дата в истории космонавтики - 60-летие образования первого Отряда космонавтов. Это событие предшествовало началу космической эры человечества.

Общее настроение членов первого Отряда выразил летчик-космонавт СССР Г.С. Шонин:

«Мы были счастливы и горды, что стояли у истоков пилотируемых полетов в космическое пространство ... Нам повезло: мы родились вовремя! Пятью годами раньше - не подошли бы по возрасту; пятью годами позже - пришли бы уже на проторенный путь. И в том, и в другом случае за нас это великое дело сделали бы другие».

12 апреля 1961 года. Этот день объединил все народы Земли. Планета ликовала! Люди обратились к небу, осознав себя причастными ко Вселенной, осознав общность всего человечества...

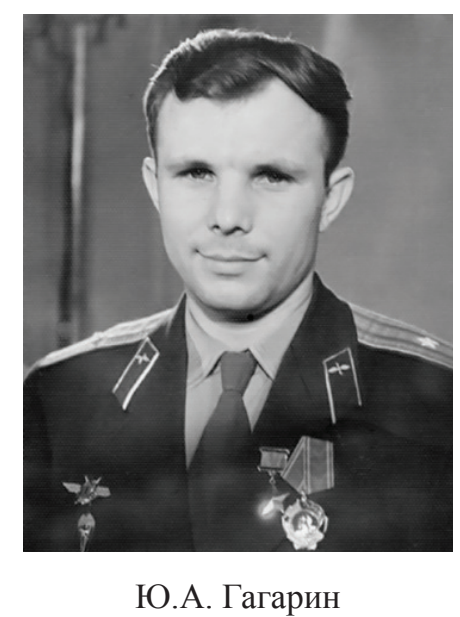

«Облетев Землю на корабле-спутнике, я увидел, как прекрасна наша Планета. Люди, будем хранить и приумножать эту красоту, а не разрушать еe!...»

Юрий Гагарин нес людям радость, улыбку, мир!

Трудно себе представить, что чувствовал Юрий перед полетом. Но его знаменитое «Поехали!» было выражением уверенности и готовности. Он верил в технику, верил Сергею Павловичу Королёву, был уверен в себе. 


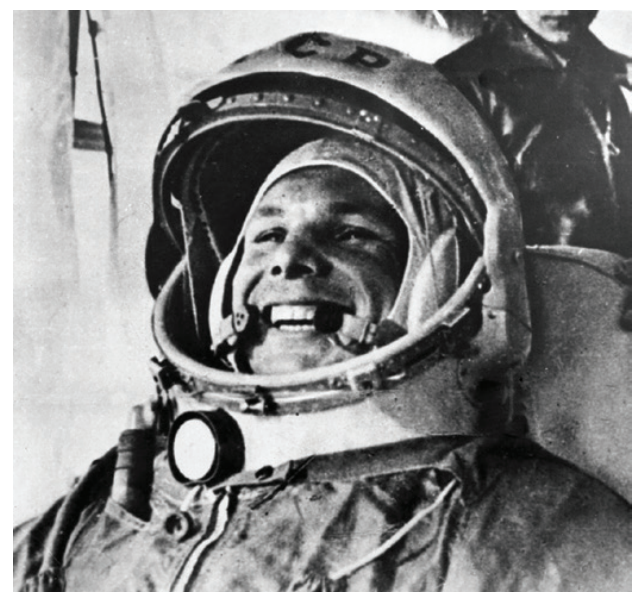

12 апреля 1961 года

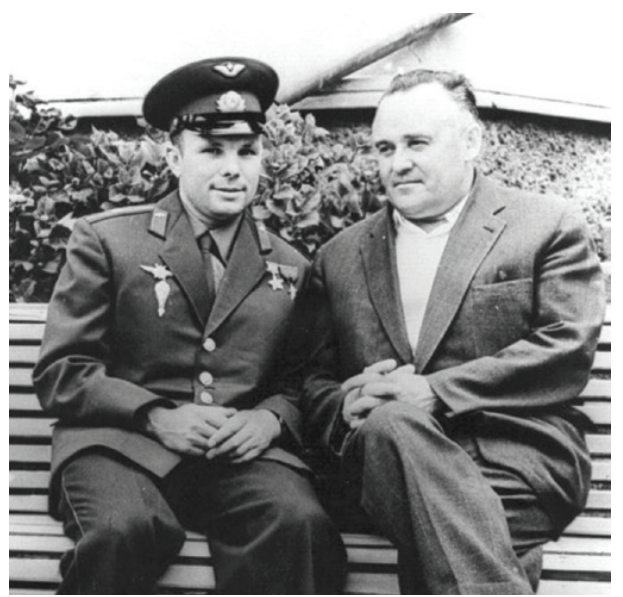

Ю.А. Гагарин и С.П. Королёв

«Я знаю, что соберу всю свою волю для наилучшего выполнения задания», - сказал он перед стартом.

Следует отдать должное и всем остальным космонавтам первого Отряда: они шли в неизвестное... Волею судьбы Юрий Гагарин стал первым (!) испытателем и космической техники, и человеческих возможностей. Он сделал «первый шаг» и показал, что человек в космическом полете может жить и работать. «Он всех нас позвал в космос...», - скажет позднее Нил Армстронг - первый человек, ступивший на поверхность Луны.

Почему же был выбран Юрий Гагарин!?

Первый начальник Центра подготовки космонавтов Е.А. Карпов рассказывал, что при отборе кандидата на первый космический полет для членов Государственной комиссии не все было однозначно: в Отряде был более опытный космонавт - инженер, летчик-испытатель Владимир Комаров. Но выбор остановили на молодом летчике Гагарине, полагая, что его личностное обаяние, открытая располагающая улыбка будут поняты и приняты людьми всех стран и национальностей.

Выбор Юрия Гагарина был одобрен главным конструктором С.П. Королёвым. Он душой принял Юрия, поверил в него, в его способности, выдержку, мужество. Гагарин взял позывной на полет - «Кедр» - исконно русский, сибирский, необычайно красивый и могучий... «Кедр! Я - Заря-1. Как меня слышите? Прием» - впервые полетел над планетой голос Сергея Павловича Королёва...

«На второй день после возвращения из космоса Юрий сделал обстоятельный доклад о работе систем корабля, подробно до мелочей рассказал об увиденном и пережитом». (Г. Шонин) 


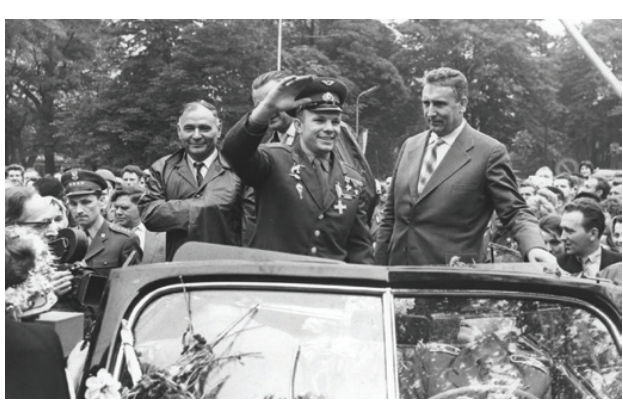

Ю.А. Гагарин во время визита в Польшу, 1961 г.
С уверенностью можно сказать, что каждый из выбранной на первый полет шестерки космонавтов смог бы выполнить программу первого полета. Но Земля встречала именно Юрия Гагарина! Он вошел в историю человечества с улыбкой! «Первый навсегда»удачное название книги о Гагарине, изданной к 50-летию космического полета.

Недаром говорят, что главным результатом полета был он сам - обыкновенный человек в необычной ситуации. Полет и обстановка после полета раскрыли личность Юрия Гагарина, востребовали его потенциальные, природные качества. Он обладал редкостным даром общения, отношения к людям: доброжелательность, искренность, открытость, живой ум, легкость слова, шутка, улыбка. Его знали все люди планеты.

«Полет Гагарина потряс весь мир. Люди всей планеты хотели видеть и сльшать первого землянина, побывавшего в загадочной Вселенной. Гагарин стал самым популярным человеком планетыл... За три с половиной месяиа после полета он совершает второе кругосветное путешествие. На этот раз по земле и по воздуху». (Г. Шонин)

Первый человек, ставший гражданином планеты! Он осознал и принял эту миссию, принял ответственность такой высокой общественной позиции. Человек долга, он подчинил свою дальнейшую жизнь служению стране, людям, отдавая этому все свое время и душевную энергию...

После полета жизнь Гагарина была очень насыщенной и яркой: встречи с рабочими коллективами, поездки по городам и странам, напряженная работа в Центре подготовки космонавтов и учеба в Военно-Воздушной академии имени Н.Е. Жуковского. Времени не хватало, приходилось пропускать учебные занятия. Преподаватель термодинамики Т.М. Мелькумов так комментировал общественную занятость первых космонавтов: «Ну, что же?! Пассажиры приходят и уходят, а поезд идет...» и продолжал лекцию. В академии Юрий увлекся аэродинамикой и под руководством профессора С.М. Белоцерковского защитил диплом инженера.

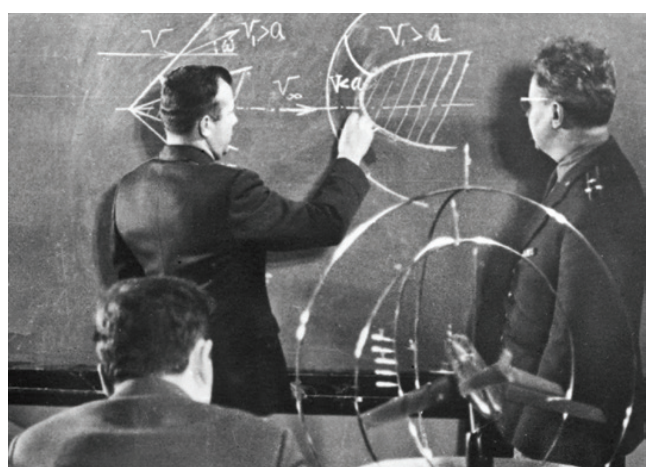

На занятиях в академии имени Н.Е Жуковского 
Юрий Гагарин был командиром Отряда космонавтов, позднее - заместителем начальника Центра по летно-космической подготовке. Уверенный, деловой, требовательный, заботливый. Он большое внимание уделял подготовке женской группы Отряда космонавтов. Часто вечерами беседовал с нами, интересовался успехами, трудностями при тренировках, давал ценные советы, рассказывал о себе...

Юрий Гагарин провожал в полет всех своих друзей космонавтов, всег-

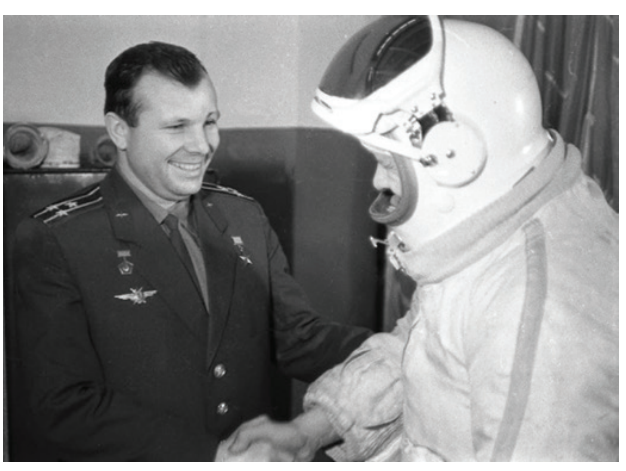

Ю.А. Гагарин напутствует

Е.В. Хрунова перед полетом да был на связи с орбитой, всегда был рядом в трудную минуту, заряжая уверенностью и оптимизмом.

Он во всем был лидером: и на службе, и на отдыхе, и на субботниках (Звездный городок в то время строился). Легкость в общении, умение делать добро вызывали всеобщую любовь и уважение. Его авторитет был настолько велик, что к нему шли с любыми проблемами, и он с готовностью помогал людям, осознавая, что может помочь, и считал это своим долгом.

«К нему тянулись люди, и он шел к ним навстречу с открытой душой и добрым сердием». (Г. Шонин )

В Отряде сложилась традиция: отмечать «праздником Нептуна» важное для слушателей-космонавтов событие - сдачу госэкзамена и переход в категорию космонавтов. Коллектив Центра, тогда еще немногочисленный и дружный, как единая семья, собирался в бассейне. Выплывала резиновая лодка, на которой восседал Владыка подводного царства в короне и с трезубцем в руках, со своей свитой. Сквозь усы и бороду Нептуна светилась улыбка Гагарина... После ответов на его сложные, содержащие юмор, вопросы и обязательной «морской» купели космонавт получал памятный диплом с автографом Нептуна.

Юрий мечтал о новом космическом полете и добился своего - был включен в группу космонавтов по подготовке к первому полету корабля «Союз». И дублировал В.М. Комарова... ...

Богатые природные способности, преданность авиации, любовь к полетам, готовность служить Космосу открывали перед ним широкие перспективы...

В Центре подготовки Юрий Гагарин навсегда остался в строю космонавтов. Его фотографии - во всех рабочих комнатах и на тренажерах. Он улыбается на борту МКС в полете. Каждый экипаж перед полетом приходит в Музей космонавтики Звездного городка в кабинет Ю.А. Гагарина, где 
полностью сохранилась его рабочая обстановка: книги, бумаги на столе, карта во всю стену и глобус Луны, подаренный В.П. Глушко с пожеланием полета на Луну. Космонавты расписываются в исторической Книге Памяти, подтверждая готовность выполнить очередной полет в космос...

В день 10-летия первого космического полета (апрель 1971 года) в Звездном городке был торжественно открыт памятник Юрию Гагарину. В гражданском костюме, с цветком в руке он смотрит на северо-восток и улыбкой встречает каждый новый

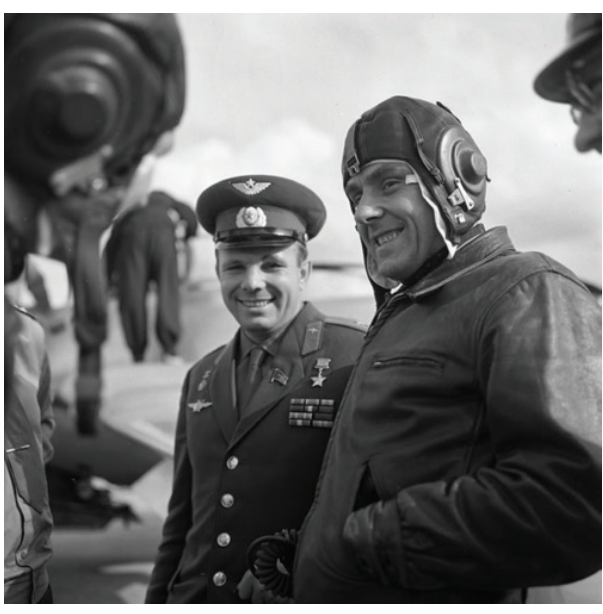

Ю.А. Гагарин и В.М. Комаров день... Здесь проходят все торжественные мероприятия Центра и Звездного городка, вместе с Юрием Гагариным встречаем космонавтов после полета... Сюда приходят люди с цветами, своими мыслями и любовью к тому, кто «встал на память»... Жизнь и полеты продолжаются...

Уже давно в Отряде космонавтов сложилась традиция: 9 марта - день рождения Юрия Гагарина - отмечать на его Родине в городе Гжатске (ныне город Гагарин).

«Он родился в этих краях, здесь прошло его детство ... Сюда, к землякам, он приезжал, чтобы отдохнуть после напряженной работы, чтобы, как Антей, набраться новых сил от родной земли». (Г. Шонин)

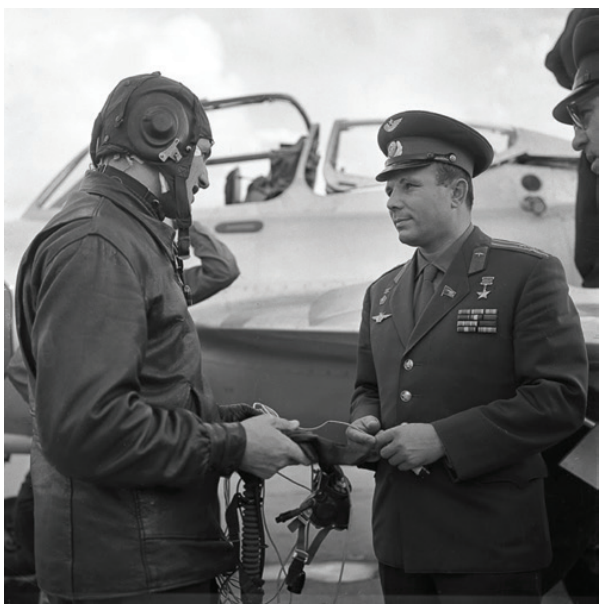

Б.В. Волынов и Ю.А. Гагарин на Чкаловском аэродроме
В этот день в город Гагарин едут космонавты, вернувшиеся из полета, и отчитываются перед жителями города о проделанной в космосе работе. Приезжают и кандидаты в космонавты, посещают деревню Клушино, с трепетом заходят в Дом-музей семьи Гагариных, где родился Юрий, и обязательно пьют свежую холодную воду из колодца рядом с домом. Это тоже традиция: мысленно принять эстафету, проникнуться духом, приобщиться к братству космонавтов, утвердить свою мечту и надежду! 
Юрий Гагарин всегда с нами. Его имя - в названии городов, улиц, учебных центров. Ему посвящаются стихи и песни, и образ его, как и любовь к нему, передается из поколения в поколение.

«Знаете, каким он парнем был,

На руках весь мир его носил...»

...«Не будет, не будет полета последнего,

Помнят люди лишь Первый полет...»

Далеко на Севере на о. Самуила (о-ва Комсомольской правды) есть мыс Юрия Гагарина. Из истории Арктики известно, что знаменитый полярник А.Ф. Трешников с экспедицией оказался здесь в день полета Юрия Гагарина и назвал его именем красивый скалистый мыс! Если представить его летом и рядом суровые волны океана, создается мужественный образ, созвучный с Первым полетом в Космос! Утес будет жить века, как и память о Гагарине.

\section{ЛИТЕРАТУРА}

[1] Шонин Г.С. Самые первые.- М.: «Молодая гвардия», 1976 г. - 127 с.

\section{REFERENCE}

[1] G.S. Shonin. The first ones. - Moscow: "Molodaya Gvardia" [Young Guard], 1976. p. 127. 